\title{
The Forensics of the American Mafia
}

\author{
Jerold Zimmerman* and Daniel Forrester
}

Simon Business School, University of Rochester.

\begin{abstract}
We present an economic analysis of the American Mafia's organizational design elements that promote its survival. Over nearly one hundred years, Mafia crime syndicates adapted their task assignments, performance measures, rewards and punishments, and culture to constantly shifting external threats and opportunities. Consistent with Chandler (1962), the Mafia's strategy, its structure, and managerial processes "fit" with one another. These organizational elements complemented each other and reigned in the greed and ruthlessness of the syndicate's heinous personnel and channeled their self-interest to create high performance teams. The Mafia built a strong brand name and an enduring culture. They shunned short-termism and took the long view. The Mafia families had well-defined succession plans and dispute resolution techniques. They attracted and retained people who furthered the family's nefarious interests while purging those damaging the family. Studying how mobsters chose their organizational design elements to fit its evolving strategy vividly illustrates the fundamental organizational economic principles lawful managers must follow to build successful organizations.
\end{abstract}

Keywords: Corporate governance, compensation, incentives, corporate culture, organized crime, Mafia.

\section{INTRODUCTION}

All types of organizations, for profit, not-for-profit, lawful, and unlawful, struggle to survive in highly competitive, and constantly evolving environments. Every day iconic brands like Sears, Kodak, and Blockbuster vanish. Managers in lawful companies face disruptive technologies, groundbreaking new products, and competition from new entrants that challenge their existence. Many organizations must manage their way through a rapidly shifting world, or else fail. Yet some organized crime (mob) syndicates last decades despite massive law enforcement efforts and rival gangs directed at their daily demise. The American Mafia, which blossomed during Prohibition in the 1920 s, continues to persist in the twentyfirst century.

Besides being hounded by law enforcement and rival mobsters, organized crime cannot use traditional institutions that promote lawful commerce such as banks, which facilitate lending and financial transactions, courts, which enforce commercial contracts, and electronic technologies such as email, texts, and the world-wide-web, which expedite communication both within the firm and with suppliers and customers. Organized crime relies mostly on cash to conduct its business. Few written records can exist, lest they fall into the hands of law enforcement.

This paper provides a forensic analysis of an unlikely and novel organization's business practices-the American Mafia. We offer an autopsy of how it aligns its strategy with employee task assignments, incentives, and culture. Follow

*Address correspondence to this author at Simon Business School, University of Rochester; E-mail: zimmerman@simon.rochester.edu ing Chandler (1962), we argue that strategy execution requires four, economics-based, coordinated administrative systems that (1) delegate specific tasks to individuals or teams, (2) measure the performance of those assigned the tasks, reward/punish these individuals, and (4) create a corporate culture that supports the strategy and complements the first three elements. We refer to these four managerial processes as an organization's Four Pillars. ${ }^{1}$

We seek to make several points. First, consistent with Milgrom and Roberts (1995) we find that the Mafia's Four Pillars are complements - the marginal returns to one pillar are increasing in the levels of the other pillars. The four pillars reinforce each other. Second, observed changes in the Mafia's strategy and Four Pillars respond to environmental threats and challenges. Third, while lawful managers cannot simply mimic the Mafia's four pillars, both lawful and unlawful leaders must follow the same organizational economic principles to devise optimal structures and managerial processes aligned with its unique strategies. As no two firms have the same strategy, they cannot share the same Four Pillars. Finally, the fourth pillar, corporate culture, defines and communicates the unique, often immoral values held by members of the Mafia and attracts people with these values. Its culture rewarded productive Mafioso with safety, a sense of belonging, camaraderie, and recognition.

Our forensic analysis is not intended to romanticize or rationalize the Mafia, the people involved in these illegal pursuits, or their behavior. These criminals cause enormous

\footnotetext{
${ }^{1}$ The first three of the Four Pillars are based on the three-legged stool from Brickley, Smith, and Zimmerman (2016), and the fourth pillar, corporate culture, is based on Zingales (2015).
} 
damage to society and our families. They consume inordinate criminal justice resources to constrain their monstrous activities. However despicable the Mafia, it devised management processes and policies-Four Pillars - that channel mobsters' self-interest to supply illegal goods and services that generate profits for the bosses while eluding law enforcement and rival gangs. Military strategists continue to study the fighting tactics perfected by Genghis Khan, the 13th century Mongol ruler, who captured the largest land empire in history (the size of Africa), even though his conquests allegedly claimed 40 million lives (11 percent of the world's population). ${ }^{2}$ While we recoil from the depravity of organized crime, their leaders followed the same fundamental economic principles to construct their Four Pillars lawful managers must follow. Moreover, a better understanding of their management techniques allows law enforcement to deploy anti-crime strategies to combat them.

To fully appreciate the development and evolution of the Mafia's Four Pillars, we first provide a short biography of Joe Bonanno, the founder of the Bonanno crime family in the 1930s. He set the corporate culture of his family and refined his syndicate's Four Pillars as circumstances dictated. Appreciating the complexities of constantly evolving Four Pillars next requires a history of the American Mafia, including the Bonanno family, from the 1920s to the present. Over this hundred-year period, law enforcement resources directed at the Mafia ebbed and flowed, and the ever resourceful, selfinterested, and evaluative mobsters devised new illegal rackets. The Mafia's Four Pillars adapted to these external threats and opportunities, demonstrating to lawful managers the importance of evolving one's Four Pillars. Next, we describe the Mafia's Four Pillars and the forensics of these practices. This paper concludes with a summary of how the Mafia constantly realigns its strategy and business practices using widely accepted economic principles.

\section{JOE BONANNO}

"My name is Joe Bonanno. I am seventy-eight years old and a grandfather. I've often been described as a gangster, a racketeer, a mobster. ... I'm supposed to be, or to have been, or to have wanted to be, the 'boss of all bosses' ... whatever that means. At one time or another, I have been accused of trying to 'take over' New York, California, Arizona, Wisconsin, Colorado, Alaska, and choice provinces of Mexico and Canada too." ${ }^{3}$ In 1931, at the old age of twenty-six, Bonanno found himself the youngest boss of one of the five New York City Mafia families that he ruled until he retired in 1968.

Bonanno exemplified how to engineer the Four Pillars to achieve his nefarious ends. Primarily, he was known for creating a family composed several hundred "made men" and thousands of associates and wannabees. Under his leadership he created:

\footnotetext{
${ }^{2}$ www.history.com/news/10-things-you-may-not-know-about-genghis-khan ${ }^{3}$ Bonanno (1985) pp. 10-11.
}

- A brand ("The Bonanno Family") that continues even today;

- Numerous small, high-performance gangs led by captains and a number of associates that specialized by vice such as bootlegging, gambling, prostitution, and union extortion;

- An enduring culture of loyalty to his crime family; and

- A process whereby extremely resourceful, market obsessed, and relentless criminals were recruited.

Born Giuseppe Carlo Bonanno in 1905, his family immigrated to America in 1908 from Castellammare del Golfo, in Sicily, and settled with other Castellammarese in a tight-knit Brooklyn neighborhood. Around 1900, Sicilian immigrants from five different regions of Sicily settled in different sections of New York City, which were to become the five NYC Mafia families. ${ }^{4}$ Joe's parents moved the family back to Sicily when he was seven to settle a conflict with a rival family. Bonanno grew up in Sicily but slipped back into the United States in 1924 after Mussolini came to power.

At age twenty, Bonanno went to work during Prohibition for a close family friend, Salvatore Maranzano, who operated a string of illegal whiskey stills in Pennsylvania and upstate New York. Maranzano took Joe under his wing and assigned him and his armed squad the task of protecting the whiskey trucks from hijackers. Under Maranzano's tutelage, Joe quickly learned and began running various rackets for his mentor, becoming his number two guy. After Maranzano's murder in 1931, the remaining crew leaders selected Joe to head the family, soon to be renamed the Bonanno Family. The family's primary businesses involved bootlegged whiskey, gambling, and loan sharking. Joe married that same year, had three children, and became a naturalized U.S. citizen in 1945.

Over the years, Bonanno acquired ownership stakes in a number of lawful businesses including coat factories, a linen supply, cheese factories, funeral homes, and a trucking company. Some claim the resourceful boss designed a doubledecker coffin with a secret compartment under the actual corpse allowing his funeral homes to dispose of an unwanted second body. ${ }^{5}$ Bonanno acquired these business interests by helping the owners "solve" problems they had with other companies, labor unions, or corrupt police. Bonanno went on to engineer monopolies in laundry services for restaurants and mozzarella cheese in the New York area. ${ }^{6}$

Despite running one of the five NYC Mafia families, he managed to stay off the police radar. That changed in 1957 when police questioned him about the very public NYC execution of fellow mob boss Albert Anastasia and then again after police raided a home in Appalachia, New York where over one hundred Mafioso were meeting. This highly publicized raid of a special underworld assembly created a media

\footnotetext{
${ }^{4}$ Ibid., p 88.

${ }^{5}$ Raab (2005) p. 39

${ }^{6}$ Ibid., p. 93.
} 
frenzy and resulted in a 1959 indictment of Bonanno on charges of conspiracy to obstruct justice. A heart attack postponed his trial, and the charges were later dropped.

In 1964, just before he was scheduled to appear in front of a federal grand jury, two mob gunmen abducted him off a Manhattan street. Authorities theorized the kidnapping involved a power struggle among a couple of the five families. Some thought Bonanno was seeking to expand his empire. After six weeks, his captors released him. Worried that other Mafioso would whack him, Bonanno went into hiding for two years - often in a safe room built in his Tucson Arizona house. During his absence, his son and other Bonanno loyalists struggled over control of his crime family. After completely going off the grid, he returned to NYC where he engineered a truce with the other families. He agreed to retire and move to Tucson, and in return his adversaries allowed him to live. He sold his beloved fourteen-room colonial house surrounded by 280 acres outside of NYC, his regal mansion on Long Island, and severed all ties to New York.

Bonanno's so-called retirement in 1968 proved anything but tranquil. A rogue FBI agent trying to create a war among Bonanno and other Arizona Mafia transplants threw a bomb at his house, injuring no one. In 1969, the government charged him with trying to extort false testimony to obtain a new trial for an imprisoned Mafia buddy. He was acquitted. ${ }^{7}$

In 1983, the government secured its first conviction of Joe Bonanno on obstruction of justice charges stemming from an alleged money-laundering investigation into his sons.

Sentenced to five years, he served eight months. That same year, Bonanno did a most incredible thing, he published a tell-all book, A Man of Honor: The Autobiography of Joseph Bonanno (with S. Lalli). The book romanticizes the Sicilian Tradition and characterizes him as "a venture capitalist." also provided a treasure trove of information for federal prosecutors. A young U.S. attorney, Rudy Giuliani, recalls "I realized that Bonanno's description of how the families were organized provided a road map of precisely what the (federal) statute was designed to combat. ...

As soon as I became the U.S. Attorney I was able to hoist Bonanno by his literary petard"9

A federal judge in 1985 ordered Bonanno to testify about how the five families functioned as described in the book, but he claimed poor health prevented his testimony. His refusal landed him back in a federal medical prison to serve a fourteen-month stretch. After returning to his Tucson home, and in poor health, Bonanno suffered a stroke and died in 2002. Joe survived 97 years and his family still operates today. In 2019, a jury acquitted the reputed current Bonanno crime family boss and his close advisor on charges of loansharking, drug dealing and violent extortions of New York area businesses from 2002 through $2018 .^{10}$

\footnotetext{
${ }^{7}$ Bonanno (1985) p.337

${ }^{8}$ Ibid., p. 154

${ }^{9}$ Raab (2005) p. 259.

$10 / /$ nypost.com/2019/03/13/reputed-mobsters-acquitted-in-racketeering-andextortion-case/
}

\section{THE CONSTANTLY CHANGING ENVIRONMENT FACING THE AMERICAN MAFIA}

The American Mafia, sometimes called "La Cosa Nostra" including the Bonanno Family, traces its roots back to Sicily two thousand years ago. During this period, the Phoenicians, Greeks, Romans, Arabs, French, Spanish, Austrian, and even hostile Italian armies subjugated the Sicilian population. ${ }^{11}$ To survive, Sicilians developed a culture of contempt for governmental authorities, and relied on their extended family and close friends for justice. The culture involved the ideal of manliness or "omertá"-noncooperation with authorities, self-control in the face of adversity, and vendetta where blood washes blood. Any offense to the family was avenged, no matter what the consequences. Neither government nor the church was to be trusted. The only basis of loyalty was to family. ${ }^{12}$ Lacking reliable public institutions for security, Sicilian clans relied on secrecy, negotiation, and vendetta for private justice. These clans consisted of "Men of Honor" who acted as middlemen, facilitators, and brokers. With large networks of friends, they could help their villagers recover stolen property from bandits, usually by buying it from the thief and keeping a small fee. These Men of Honor used any means, including violence, to enforce justice in their communities. Even Sicilian clergy trusted these men and their connections to safe guard church property.

These secret Sicilian societies evolved from disorganized bands for self-defense into Mafias between 1860 and 1890 following the unification of Italy. The new Italian government gave local governments the power to police public order and private property. Unfortunately, the local police were no match for bandits. Absentee landowners, and in particular wealthy citrus farmers who lived in large towns, turned to local mafias to run their estates, protect their orchards, and insure the safe transportation of the valuable fruit to Sicilian ports to be exported overseas. ${ }^{13}$

One Sicilian Mafia in 1872 adopted a formal governing decree, a key piece of its Four Pillars, stating the following commitments each member makes: ${ }^{14}$

- "To exchange help and aid to a member, and wipe out offenses against any member with blood.

- "To assist and carry out the defense of members who fell into police hands; to cooperate in securing witnesses in his defense and to contribute to paying defense costs.

- "To distribute among the members (according to executive decisions) the proceeds of ransoms, extortions, robberies, and other crimes perpetrated in the common cause; those most in need to receive special consideration.

- "To keep the oath and to maintain secrecy on pain of death within 24 hours for a violation of the statute's provisions."

\footnotetext{
${ }^{11}$ S. Raab (2005) p. 13 and Bonanno, p.30.

${ }^{12}$ Abadinsky (2017) pp. 63-4.

${ }^{13}$ Anderson (1995) pp. 33-54.

${ }^{14}$ Nelli (1976) p.15.
} 
The Four Pillars of these Mafias eventually found their way to America, including the code of silence, which forbade cooperating with public authorities ${ }^{15}$. Between 1890 and 1920, roughly four million Italians and Sicilians settled in America. While the overwhelming majority were lawabiding, a small number of criminals, knowledgeable of Mafia organizations, immigrated. Virtually all American cities had local Mafiosi, located in "Little Italy's," involved in extortion, gambling, and the manufacture of low-cost, untaxed alcohol, called "bootlegging." By 1901, NYC extortion and blackmailing gangs operated on a large scale. ${ }^{16}$ While the Sicilian Mafia in Italy had flourished since the late-19th century, in 1920 the Fascist Mussolini regime attacked Sicilian Mafiosi and drove many to foreign lands, where they quickly resumed their bootlegging and came to control the burgeoning American Mafia. The American and Sicilian Mafias were separate entities. Nonetheless, the Sicilian and Italian immigrants adopted many of the same old-country traditions, such as omertá.

The success, survival, and wealth of the American Mafia relied on the use of coercion to eliminate competition in whatever vice the mobsters peddled. Only one mob family ran prostitution in its assigned territory. If other competing prostitution purveyors entered, prices and profits would fall. Joseph Bonanno, wrote, "One must remember that in the economic sphere one of the objectives of a (mob) Family was to set up monopolies as far as it was possible." 17 Joe understood a core economic principle - in free markets, entry drives down prices and profits - and used various means, including violence to prevent entry.

Besides forming monopolies, resourceful mobsters understood the importance of supplying a quality product, another important economic principle. For example, Meyer Lansky who ran large gambling operations from the 1920s through the 1950s knew the importance of integrity. Although it is relatively simple to rig a roulette wheel or dice game for short-term profits, once the gamblers learn of the deception, that casino is dead as word spreads. Lansky stated proudly, "Everyone who came into my casino knew that if he lost his money it wouldn't be because he was cheated." 18

The Eighteenth Amendment to the United States Constitution began National Prohibition $(1920$ - 1933) and transformed small-time Mafiosi street hoods into multimillionaires.

Outlawing the manufacture and sale of alcohol supercharged the American Mafia's growth. Virtually all adult Americans now sought a highly prized, but banned substance-alcohol. Overnight, banning an entire legal industry, created a new black market - the production and distribution of booze. While some of the local mafias already were in the bootlegging business, Prohibition yielded a bonanza. One 28-yearold Italian mobster, Lucky Luciano, bragged his gross take from bootlegging alone in 1925 was $\$ 12$ million, and he

\footnotetext{
${ }^{15}$ Hobsbawm (1997) and Nelli (1976) p. 14.

${ }^{16}$ Nelli (1976) p. 72.

${ }^{17}$ Bonanno (1985) p. 79

${ }^{18}$ Lacey (1991) p. 86
}

cleared \$4 million in profits after paying his 100-man payroll $\$ 1$ million and police protection $\$ 5.2$ million ${ }^{19}$. In today's dollars, Lucky's annual $\$ 4$ million profit translates to over \$58 million.

Besides generating enormous profits, Prohibition's bootlegging created very efficient syndicates for producing and supplying huge quantities of beer and whiskey. Competition among gangs drove out incompetents. As described by Economic Darwinism, only those with superior management and organizational practices survived. Those families with internal operating policies and procedures - their Four Pillarsthat created high performance teams, which dominated competing families, persisted. Criminals with inefficient or wrong-headed Four Pillars died off.

The surviving Mafiosi, most in their twenties and thirties, developed expertise in organizing small armies of smugglers, truckers, and gunmen. They became adept at laundering money to dodge tax-evasion indictments. Those with these skills became rich and powerful, with the resources to buy protection from local law enforcement ${ }^{20}$. One Chicago mobster, Al Capone, ran a very efficient operation by keeping detailed books for each department itemizing that department's expenditures and income. He raised hell about unprofitable departments to the point of eliminating them and/or dishonest subordinates. Unfortunately for Capone, these meticulous records on the profits of his gambling houses and speakeasies proved invaluable when the IRS prosecuted and convicted him of income tax evasion in $1931 .{ }^{21}$

Whereas New York City, America's organized-crime capital, contained five Mafia families, every other major U.S. city had just one family. In the late 1920s, a bloody power struggle erupted between New York City's two largest ItalianAmerican criminal factions. In 1931, one family led by a Sicilian-born crime boss, Salvatore Maranzano, murdered the other faction's leader and crowned himself the "capo di tutti capi," or boss of all NYC bosses.

Unhappy with Maranzano's claiming control of all NYC Mafia families, the rising mobster Lucky Luciano, with his own family, executed Maranzano in a Brooklyn restaurant that same year. Luciano then convinced all of the other crime families around the country to form a quasi- governmental council, called the Commission, to coordinate their activities and adjudicate disputes among the families.

Not content with the millions made on bootlegging, resourceful and self-interested Mafiosi expanded their other illicit enterprises, notably gambling, prostitution, extortion, theft, and loansharking. These mobsters' behavior corroborates the economist's assumption that people are selfinterested, evaluative, and resourceful with insatiable wants. Prohibition saw the emergence of a number of innovative criminal experimenters who created unlawful institutions and procedures copied by other crime syndicates across the coun-

\footnotetext{
${ }^{19}$ Davis (1993) p. 35

${ }^{20} \mathrm{Raab}(2005) \mathrm{p} 36$.

${ }^{21}$ Nelli (1976) p. 178.
} 
try. Their Four Pillars, shaped in the 1920s and 30s, provides the template still followed by families today. ${ }^{22}$ To illustrate the scale of just one part of Lucky Luciano's nonbootlegging empire, in 1936 Luciano was found guilty of sixty-one counts of prostitution and sentenced to a term of thirty to sixty years in prison. The government claimed Luciano operated two hundred bordellos and employed three thousand prostitutes, grossing over $\$ 12$ million annually. ${ }^{23}$

Following the repeal of Prohibition in 1933, the always resourceful Mafia put their well- honed management skills to expanding its racketeering activities to replace bootlegging.

Racketeering includes gambling, loansharking, narcotics, kidnapping, arson, bribery, and extortion. Gambling again became the largest single income source in the 1930s, as it was before Prohibition. ${ }^{24}$ The mob eventually found lucrative markets selling untaxed cigarettes, extorting labor unions and legitimate businesses such as construction, garbage collection, and New York's garment industry.

The management skills refined by the Mafiosi during Prohibition paid huge dividends when World War II created rationing and black markets for hard to find goods. Gasoline, tires, meat, butter, canned goods, sugar, and other staples required government issued stamps and coupons to purchase them. Self-interested, resourceful, and evaluative mobsters saw a lucrative opportunity. They bought rationing stamps and coupons from corrupt government employees or counterfeited them and resold them on the black market at huge markups. ${ }^{25}$

In the 1950s, the mob expanded its gambling into Nevada as Las Vegas bloomed in the desert. The mob's Commission declared Las Vegas an "open city," meaning any family could open a casino. Nevada's naïve gambling regulators welcomed the mobsters, encouraging them to open casinos to fill the State's coffers with taxes on the casinos' profits. Between 1950 and the 1970s, the Mafia executed a billiondollar fraud against the State of Nevada. Under Nevada State law, each casino must pay the state a fraction of its winnings. Each night, casinos take all the cash into a room where employees count the money as Nevada State regulators oversee the process. The enormous amounts of money facilitated the mobsters' ability to corrupt the state regulators. The mobsters would skim some of the cash before counting it as profits, stuff it into suitcases, and fly it back east to the five families. The FBI estimates the Mafia's skimming of Las Vegas casinos amounted to about $\$ 1$ million a day. ${ }^{26}$

By the 1950s, thousands of Mafia wiseguys, assisted by tens of thousands of associates, operated in the five NYC-area families. These five families constituted 40 percent of the five thousand Mafiosi in the country's twenty-four crime families. ${ }^{27}$ One 1960s' government study estimated the American Mafia's annual profits at $\$ 7$ billion, exceeding the

\footnotetext{
${ }^{22}$ Ibid., p. 257-8.

${ }^{23}$ Abadinsky (2017) p. 45.

${ }^{24}$ Nelli (1976) 126.

${ }^{25}$ Raab (2005) p. 75

26 //lasvegassun.com/news/2008/may/15/mob-ties/

${ }^{27} \operatorname{Raab}(2005)$ p. 92.
}

combined earnings the ten largest U.S. corporations. ${ }^{28}$ The mob hijacked five to six trucks every week in the New York City area. They stole $\$ 2$ million worth of Kodak film, $\$ 500,000$ of clothing in route to Saks Fifth Avenue, and $\$ 100,000$ of coffee.

Another popular mob racket involved corrupting union officials, thereby milking the union pension funds. Once in control of a union, the mobsters would extort unionized companies with Mafia-enforced work stoppages unless these companies paid the union for labor peace. ${ }^{29}$ The mob then parlayed their control of powerful labor unions into the construction business.

Several New York City families began enforcing cartels among construction companies. Federal and state antitrust laws prohibit lawful firms from forming a cartel to collude in fixing prices. Suppose all the concrete companies in the NYC area decided to form an illegal cartel to raise the price of concrete above the market price. Such a cartel only succeeds by preventing members from cheating. Enter the Mafia. A series of New York Times articles published in 1982 described the Mob's hammerlock on the city's billion-dollar construction industry. The Mafia with their corrupt union partners siphoned millions of dollars by rigging bids and inflating building costs on major construction projects. One story described how the Mob-linked NYC concrete cartel contrived to produce the highest concrete cost in the nation. The family decided which concrete company would win the bid and instructed the other bidders to submit higher bids. In one project, state auditors estimated that the concrete work should cost $\$ 18$ million, including a profit for the contractor. However, only two Mob-controlled concrete contractors bid $\$ 30$ million and \$40 million, respectively. Eventually, the builder negotiated one contractor down to $\$ 26.5$ million, still $\$ 8.5$ million above the New York State auditor's estimate. ${ }^{30}$

The NYC families provided similar cartel-enforcement services in garbage collection, local trucking services, commercial laundries, clothes manufacturing, food distribution, truck transportation around airports and docks, and construction. The fees charged by the Mafia for these cartel-enforcement services appear quite modest, only $2 \%$ of the contract price. By keeping their fees low, most of the inflated prices went to the contractors, thereby creating loyal clients. In this way, the families created a durable business model, not based on Mafia greed but rather on sound, if not illegal, commercial practices. $^{31}$

According to a 1986 estimate, the Mafia earned approximately $\$ 50$ billion annually at an annual cost to the American economy of \$18 billion in economic output. ${ }^{32}$ A 1990's study by the New York Police Department estimated that New Yorkers wagered more than $\$ 1$ billion annually on the Super Bowl with the NYC families. Since the mob keeps 15 percent of every dollar bet, on one game and in one day, the

\footnotetext{
${ }^{28}$ Ibid., p. 156.

${ }^{29}$ Ibid., p. 11.

${ }^{30}$ Ibid., p. 230.

${ }^{31}$ Mbetta and Reuter (1995) pp. 116-135

${ }^{32}$ Wharton Econometrics Forecasting Associates. (1986) pp. 423-425.
} 
five families made $\$ 150$ million. One enterprising NYC Mafiosi operated forty sports-betting outlets that grossed over $\$ 300$ million a year and profits of $\$ 45$ million. ${ }^{33}$ These enormous profits earned by the Mafia from the 1930s through the 1990s attest to the ability of the mob to create and maintain monopolies in their various rackets. These monopolies only exist because the mob effectively limits entry by would-be competitors.

The Feds dealt a huge blow to the Mafia in a series of criminal cases in the 1980s. It took six years in the late 1970s for an undercover FBI agent to became an associate in one of NYC's most powerful families. During that time, he meticulously documented hundreds of criminal acts. The FBI began wire taping mob bosses' cars, homes, and social clubs. Then, Joe Bonanno's explosive book, A Man of Honor provided the young, ambitious U.S. Attorney, Rudy Giuliani, a roadmap for how the Commission actually operates. Based on the Bonanno book, the wire taps, and the testimony of the undercover FBI agent, Giuliani and his team secured over a hundred convictions. Eventually, the boss of every single NYC Mafia family would be indicted, in prison, or dead before the trials ended. ${ }^{34}$ Following these trials, the Mafia lost control over many labor unions and much of the construction trades. So, always resourceful, they followed the money-they turned to Wall Street.

They began muscling brokerage firms. In one scheme, they bought large amounts of small, thinly traded, low-priced shares called "penny stocks." Then the mob fraudulently hyped their stocks and created "boiler rooms" within their controlled brokerage firms, where brokers called small investors promising very high returns. The investors, many of them elderly, bought the mob's penny stocks at highly inflated prices. These "pump and dump" schemes defrauded investors of at least $\$ 50$ million. In 2000, the Federal government arrested and charged 120 individuals, many of them Mafioso. The U.S. Attorney called the action the "largest securities fraud takedown in history" and the "biggest dent we've ever made in the mob's influence on Wall Street." 35

While, the power of the American Mafia continued growing through the 1970s, the 1980s Federal cases that eliminated all five crime family leaders significantly reduced its influence.

Yet, the Wall Street Journal in 2014 estimated several hundred mobsters remained in the five major New York families, down from 3,000 in the early 1970s. Two factors explain this trend: new laws and increased difficulty recruiting new members. First, the Racketeer Influenced and Corrupt Organizations (RICO) and the Continuing Criminal Enterprise (CCE) statutes gave Federal prosecutors, like Rudy Giuliani, powerful tools to prosecute the bosses, not just the lower-level criminals caught committing the crime. To secure a conviction under RICO the Feds need only show the Mafia boss' involvement in a conspiracy. The RICO statutes provided for Federal sentences of 20 to 40 years without

\footnotetext{
${ }^{33}$ Raab (2005) pp. 312-3.

${ }^{34}$ Pistone (1987) pp. 141-142.

${ }^{35}$ Walsh (2000).
}

parole, thereby creating strong incentives for indicted mademen to cooperate with the government. These statutes spurred a surge of deserters who became government informers, which further diminished the Mafia.

A second reason for the decline in the American Mafia is the Americanization of the Italian-Sicilian communities. Immigrants in the 1900s had few lucrative employment alternatives, and so some turned to crime. Like the Irish and Jews before them, Italian Americans could advance into American society, as exemplified by the Italian governors of New York and New Jersey, and the mayor of New York City. By the1970s, college and a respectable career became a reality for many second- and third-generation teenage Italians. Their families encouraged this choice. Without new blood and a willingness to shed it, the Mafia lost control of the New York heroin market to Mexican and African-American gangs because the Mafia never mounted a credible entry deterrent. Finally, the Mafia failed to control the cocaine market $\square$ the largest single illegal market of $\$ 40$ billion. ${ }^{36}$

By 2005, the roughly twenty Mafia families in America were practically defunct, except in the New York and the Northeast Corridor. ${ }^{37}$ Two events likely stayed the Mafia's complete extinction. First, the September 11, 2001 World Trade Center attacks dramatically shifted the government's enforcement activities from the Mafia to terrorism. The FBI reassigned more than five hundred of its eleven thousand agents from traditional crime-fighting duties to combating terrorism. At its peak in the 1990s, the FBI deployed as many as 350 agents and 100 police investigators fighting the NYC Mafia. By 2018, the FBI had only 20 to 30 agents assigned to organized crime. Second, much stricter bank regulations enacted following the 2008 mortgage meltdown and recession tightened bank lending practices forcing small businesses needing fast cash to turn to Mafia loan sharks charging as much as 3 percent interest per week.

Today's Mafia tries to remain as invisible as possible. They rely on rotating panels of leaders to run the daily business to elude police targeting any one boss, and they avoid meeting in clubs and restaurants. They have moved out of their old neighborhoods. Nonetheless, they remain resourceful. Their new scams involve offshore Internet gambling websites and trafficking prescription drugs. One law-enforcement officer said, "They're still part of the fabric of New York City. ... They're never going to go away. ${ }^{38}$

\section{THE FOUR PILLARS OF THE AMERICAN MAFIA ${ }^{39}$}

Fig. (1) displays the organization chart for the American Mafia. The Commission oversees all five families. Legitimate businesses require mechanisms to arbitrate disputes among firms and its employees and to enforce contracts. The courts and the police power of the state provide these vital services in a lawful economy. The Mafia cannot rely on these institutions to settle disputes and enforce contracts.

\footnotetext{
${ }^{36}$ Reuter (1995) p. 120.

${ }^{37}$ Raab (2005) p. 691.

${ }^{38}$ Gardiner and Shallwani (2014).

${ }^{39}$ Much of this section draws from Cressey (1969) and Abadinsky (2017).
} 


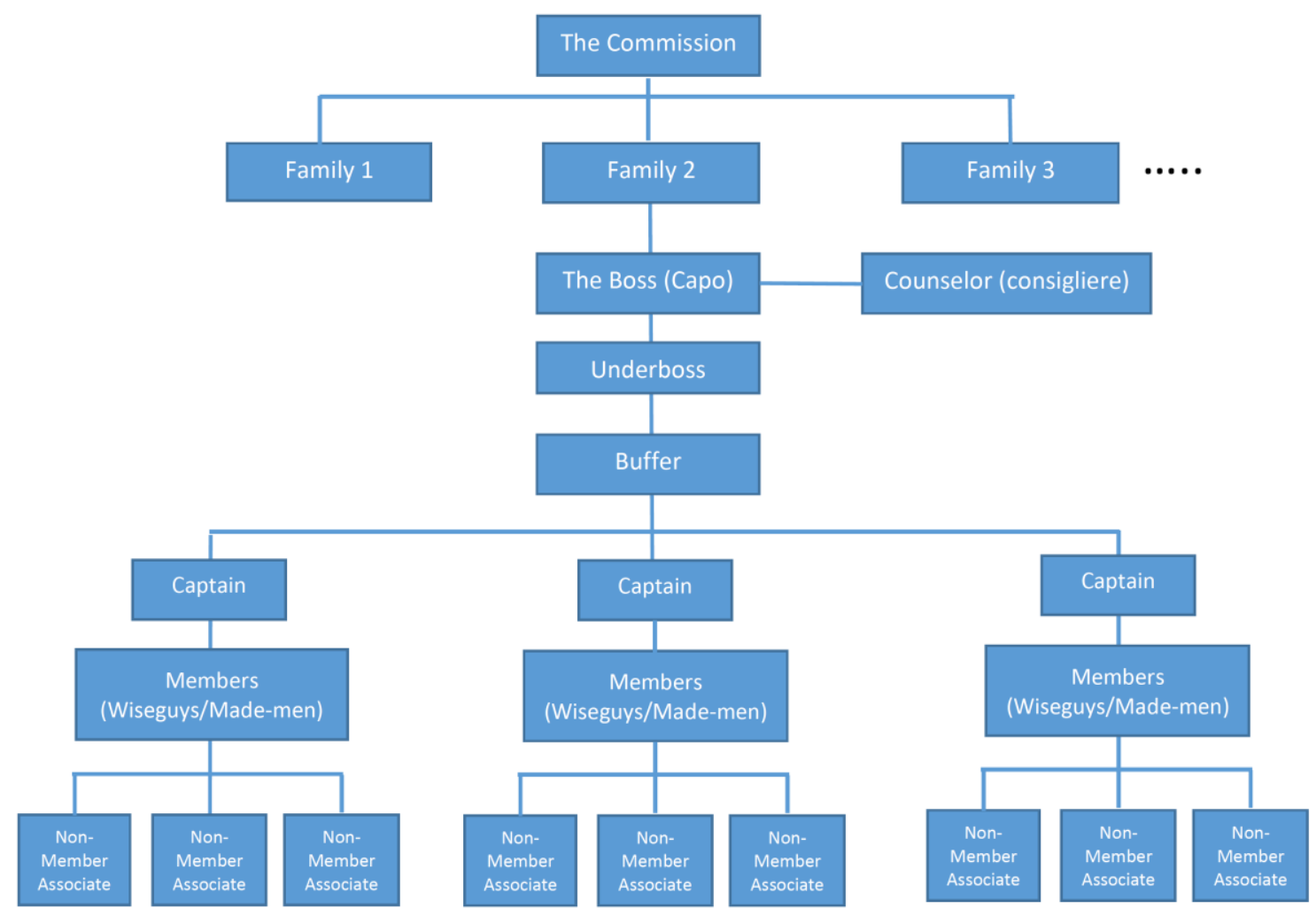

Fig.(1). Organization of the American Mafia.

Arbitrating and settling disputes between the families is the role of the Commission, initially conceived by Lucky Luciano in the 1930s. Since the 1940s, the Commission consisted of between 6 and 12 of the most powerful families in the United States and Canada. The Commission divided the U.S. into geographic territories ranging from Florida (and the Caribbean) to Nevada and California. Over time, the Commission incorporated non- Italian families into its quasigovernment structure. Every five years, all the family bosses met to pick the men to serve on the Commission.

The Commission imposed very strict rules. No made man in another family could be executed without its approval. Another rule prohibited murdering a cop or a prosecutor because that would unleash the fury of the law against the mob and harm normal business activities.

Moreover, no family could add more wiseguys (members) without the Commission's approval, thereby preventing one family from gaining power relative to the other families. Also, the Commission ratifies the appointment of each new family boss chosen by the family's captains. Since forming the Commission in the 1930s, few major wars occurred among the families.

Wiseguys still wacked each other as factions within the same family fought over control. For example, in 1985, John Gotti, a Gambino captain, seized control of the family by executing the boss and underboss. ${ }^{40}$

\footnotetext{
${ }^{40}$ Raab (2005) p. 373.
}

Under the Commission are the crime families. A boss (or capo) heads each Mafia family. Most bosses, senior citizens, after many years have gained the respect of the family and have the knowledge and political connections needed by the family. They usually lack detailed knowledge of the diverse and decentralized activities of their made-men. He primarily maintains order and focuses on maximizing the family's profits. The boss, with sole decision-making authority within his assigned city or territory, decides who becomes a member of the family, what illegal businesses members run, and divides the profits of the businesses among the family members.

The boss also arranges bail for arrested family members and orders family members to fulfill their personal obligations.

A small number of people report directly to the boss. The under-boss in each family, appointed by the boss, collects information and passes it to the boss and acts for the boss if the boss is sick or unavailable. The counselor (or consigliere), also appointed by the boss, is usually an elder statesman, semi-retired, who as a skilled diplomat defuses potential problems and helps the boss maneuver around family obstacles. To shield the boss and under boss from the police, the family uses a "buffer" to communicate directly with other family members. This complicates the task of law enforcement to prove the boss actually heads the crime family.

Several captains report directly to the boss through the buffer. Captains run the actual day-to-day rackets, and a majority of the captains must ratify a new boss. Five or six made-men or wiseguys report directly to each captain. In 1937, the largest NYC mob family contained more than three hundred 
made-men. ${ }^{41}$ These wiseguys operate the illicit enterprise for their captain, and each one can have five to ten non-member associates or wannabes helping him. Associates are not members. Made-men constantly search for lucrative opportunities to bring to their captains. Each wiseguy always has something going, always has money. You name it, they stole it from warehouses, docks, trucks, airports. Crews of mademen and associates operate as semi-independent units. For example, a wiseguy might operate gambling rackets in a specific territory in the city where the family protects him from competition and affords him police protection.

The FBI accused one NYC captain of running one of the City's biggest betting and loansharking operations with a network of more than two hundred employees that grossed $\$ 10$ million in $1977 .{ }^{42}$

In some families, made-men share roughly 15 percent of all criminal profits with their captains who in turn shares his earnings with the boss. In other families, the boss dictates what each wiseguy and captain keeps. In both cases, the family protects made-men and their captains from other criminals and provides them access to the family's network of law enforcement protection.

Made-men tend to specialize as either "earners" or "shooters." The earners generate cash for the family, whereas shooters use violence efficiently and dispassionately to keep members and outsiders in line with the boss' wishes.

Non-member associates, usually from Italian families, become members of the family by demonstrating a long history of devotion to the family and successful criminal activity. In some cases, associates may wait 15-20 years before convincing their seniors they possess traits worthy of membership. Earners have proven they can generate cash, whereas shooters, including stakeouts and wheel men have demonstrated their skills. To admit new "made" members, a captain sponsors the candidate to the boss. Prior to admission to the family, each candidate undergoes a formal background investigation, including a credit check. That captain then assumes responsibility for the new wiseguy for the rest of that captain's life in the mob. If a wiseguy rats out the gang, his sponsor usually gets hit. In a formal ceremony, involving the boss, the consigliere, the underboss, and the captain, the initiate's trigger finger is pricked, and promises loyalty and swears his life to the family.

With the Mafia operating as a giant meritocracy, its organizational structure in Fig. (1) with the boss, under boss, consiglieri, captains, made-men, and non-member associates is a very productive money machine. The Mafia created the first, modern franchising business model.

Most experts believe that Howard Johnson established the first restaurant franchise in 1932, when he let independent operators use the same name, food, logo and building design in exchange for a fee based on the restaurant's sales. The Mafia employed the franchise model whereby each wiseguy kicks back a portion of their profits and passes it up the

\footnotetext{
${ }^{41}$ Raab (2005) p. 58.

${ }^{42}$ Ibid., p. 225.
}

chain. Rather than calling it a franchise fee they termed it "tribute."

Their franchise model worked extremely well. In 1932, slot machines netted $\$ 37$ million for one NYC family. ${ }^{43}$ By producing considerable income or being a good enforcer, the wiseguy gains greater status in the family and advances to captain. Each family member specializes in what he is good at doing - earning or shooting. For example, in an ordered execution, people specialized as hit men, who carried out the killing, others were wheel men, who secured and drove the get-away car, and others were look outs. Each was skilled in his task. Besides earners and shooters, families require financiers, procurement agents, transportation experts, lawyers, and accountants, mostly non-member associates.

Two important specialized tasks were "money movers" and "corrupters." The "money mover," a key position in all families, manages the huge investments in the family's legal and illicit businesses. Large unlawful profits create two problems: hiding its true ownership and putting it to work. The money-mover, skilled in finance and with deep connections in the community, works with family members to invest their ill-gotten cash. He looks to invest in legitimate, profitable deals, without too much risk. In a typical scheme, the money-mover partners with an unethical businessman who invests in importing companies, real estate, or stocks and bonds. The money mover and his partner take a small fee with the bulk of the profits laundered back to the family members as legal, reportable taxable income. One infamous Prohibition gangster, Meyer Lansky, was known as a human cash register and ledger book. In his head, Lansky kept track of the numerous shifting deals among bootleggers transporting and protecting the alcohol, and calculating each partner's share of the profits. ${ }^{44}$

The other important position in each family, often performed by the consigliere, is the "corrupter," who bribes, intimidates, or negotiates himself into a relationship with law enforcement, public officials, and anyone else who might help protect the family from arrest and prosecution. In some cases, one corrupter specializes in bribing the police, another bribes state alcohol beverage commissioners, and a third handles the courts by fixing judges, court clerks, or prosecutors. One investigation suggested that during most of the 1960 s a large portion of the 30,000-member NYC police department received Mafia bribes for protection. ${ }^{45}$ Mobsters also use political contributions as another corruption tool. By some accounts, organized crime contributes 15 percent of the costs of local and state political campaigns. ${ }^{46}$ During the 1920s and 30s, local politicians in Republican-run Saratoga, New York allowed the Mafia to operate local casinos. In return, the mob paid Republican-party members patronage. Republican farmers received guaranteed contracts for milk,

\footnotetext{
${ }^{43}$ Ibid., p. 60.

${ }^{44}$ Lacey (1991) p. 53.

${ }^{45}$ Raab (2005) p. 160.

${ }^{46}$ Cressey (1969) p. 253.
} 
eggs, and meat supplied to the casinos. The casinos hired hundreds of part-time workers sent by the Republicans. ${ }^{47}$

Each family, like almost all other crime syndicates, prohibited female members. Females could be non-member associates, but never "wiseguys." Mafia wives assumed traditional roles of child rearing, maintaining the household, and occasionally hiding guns or contraband. Another strict rule prohibited affairs with another wiseguy's wife or girlfriend.

A critical success factor for all organizations involves the ability to recruit the right people. The Mafia is no exception. Their recruiting process starts with ten to twelve year olds, often sons, nephews, or cousins of made-men or kids of family friends. Wiseguys hangout in their neighborhood bars and social clubs. They know the tough street kids that like to fight and shoplift. The wiseguys engage these boys to run errands, first getting them food, watching their cars, and eventually picking up packages. They slowly bring them into the mob as low level associates, and give the promising ones more responsibility. Teenagers who want the life seek out more dangerous assignments. These recruits were almost always from Italian-American families who attended the same schools, formed gangs when younger, and looked up to wiseguys. They were very homogeneous in their backgrounds, desires, and goals. Choir boys, chess players, scholars, and introverts were not on a Mafia career path. Its recruitment pool failed the diversity test. Only rough and tumble kids sought the life, and Mafia families picked and retained the best.

The Mafia's Four Pillars created resourceful high performance teams that conceive new illicit money-making schemes. Consider a few examples. In 1965 a New York crew started and then ran a multimillion dollar cigarette smuggling operation. It purchased huge quantities of untaxed cigarettes in North Carolina, trucked them to New York, and sold them through wholesalers and retailers including milkmen, vending machine servicemen, and union shop stewards. ${ }^{48}$

Another resourceful Mafia wiseguy, in collaboration with some Russians, devised a scheme to steal gasoline tax receipts that netted the Mafia nearly $\$ 15$ million a month. In the 1980s, New York State changed how it collected the 30 cent per gallon gasoline tax. Previously, each gas station had to pay the State the taxes it collected. New York wanted the wholesaler who delivered the gasoline to the station to collect the tax from the station and remit it to the State.

The mobsters established "daisy chains" of dummy companies that supposedly transferred gasoline to one another using a sequence of paper transactions among five or six companies. The wiseguys used their connections with state officials to obtain licenses needed by the phony dummy companies in the "daisy chain." Mob enforcers, then collected the taxes from gasoline stations and the dummy corporations filed the necessary paperwork with state officials. When state

\footnotetext{
${ }^{47}$ Lacey (1991) p. 84.

${ }^{48}$ Cressey (1969) p. 245.
}

or federal agents came looking for the overdue taxes, they only found fictitious empty-shell companies. ${ }^{49}$

\section{THE FORENSICS OF THE AMERICAN MAFIA'S FOUR PILLARS}

The Mafia's vast amount of money provides one advantage over legitimate companies when it comes to creating high performance teams. Although lawful companies can reward their loyal employees economically, few can offer vast riches and prestige like the Mafia to motivate behavior. When mob boss Vito Genovese went to prison in 1959, at least 27 of his family's made-men were millionaires. ${ }^{50}$ Although a few high-tech firms like Google and Amazon have created enormous wealth for early hires, most legal firms operate in competitive markets, which limit the amount of profits available to attract and motivate their workers. However, mob families create and maintain local monopolies in their vices. These monopolies generate immense sums that attract young men eager to join the Mafia, even knowing the risk of getting killed or imprisoned. In other words, self-interest is an important motivator of Mafioso, as is the prestige of being a made-man. The Mafia's Four Pillars evolved to harness this self-interest to motivate high performance teams to increase their profits while insuring the survival of their families.

\section{Task Assignment Pillar}

The first pillar of the Mafia's Four Pillars involves assigning the various tasks among the family members. In other words, who makes each decision? Who becomes a made-man? Should a particular truck be hijacked? How big of a bribe should a particular police detective receive?

Economics teaches that tasks should be assigned to those mobsters with the skills and the best information to execute the task, and who have incentives to make decisions that benefit the family, not just themselves. Table 1 details the tasks and decision-making authority of the various people in the Mafia.

Since the Mafia cannot rely on local, state, and Federal government to enforce contracts and to adjudicate disputes among the Mafioso, the Mob must perform these essential functions. The boss of each family along with his consigliere and under boss make these vital decisions within the family. Bosses primarily focus on peacekeeping, and decentralize the vast majority of day-to-day decisions to their captains. The Commission enforces contracts and settles disputes among families. Besides enforcing contracts and arbitrating disputes among families, the Commission retains decisionmaking authority to ratify each family's boss, determine the number of made-men in each family, and, perhaps most important, to authorize the execution of made-men in another family. Interestingly, each Mafia family relinquishes these decisions to the Commission. The Commission can gather easily the information needed to make these very important, high-level decisions. Ceding these tasks to the Commission

\footnotetext{
${ }^{49}$ Raab (2005) pp. 301-2.

${ }^{50}$ Cressey (1969) p. 233.
} 
Table 1. Tasks and Decision-Making Authority of Mafia Members

\begin{tabular}{|c|c|}
\hline Position & Tasks and Decision-Making Authority \\
\hline Commission & $\begin{array}{r}\text { Enforces contracts and adjudicates disputes among families Sanctions killings of wiseguys in other families Ratifies } \\
\text { appointment of new bosses Determines the number of wiseguys in each family }\end{array}$ \\
\hline Boss (Capo) & $\begin{array}{r}\text { Adjudicates disputes within his family Appoints underboss, counselor, captains Ratifies new members nominated by } \\
\text { captains Decides how much profits each crew keeps Oversees money movers and corrupters Approves use of violence } \\
\text { within the family }\end{array}$ \\
\hline Underboss & Same decisions as the boss in the boss' absence \\
\hline Counselor (Consigliere) & As "corrupter" decides who to bribe \\
\hline Buffer & No decision-making authority \\
\hline Captains & Oun the day-to-day rackets in his assigned territory Choose new rackets Recruit non-member associates \\
\hline Members (Wiseguys/Made-men) & \\
\hline Non-Member Associates & Little decision-making authority \\
\hline
\end{tabular}

helps control the excessive greed of any single family boss, thereby keeping peace among the families. Failure of any one boss to accede to the will of the Commission brings the wrath of the other families. It seems to have worked, as peace among families has existed since Lucky Luciano formed the Commission in the 1930s until a brief war broke out between two families in the 1980s.

The family boss, subject to approval by the Commission for some key decisions just described, has complete decisionmaking authority within his family. Since the boss primarily maintains order, his captains with the most up-to-date information about what is happening on the streets run the rackets. The high-level decisions retained by the boss include who becomes a made-man, who is promoted to captain, and how the criminal spoils are divided among the family - the earners, the shooters, relatives of family members currently incarcerated, and so forth. The boss oversees the general operations of the money movers and the corrupters, and usually approves the use of violence on outsiders, such as a recalcitrant debtor of a family loan shark. He also has a say in new unlawful ventures. Although, he may be informed after the fact. In making these decisions, the boss has the necessary knowledge that benefits the family. If the boss makes decisions harmful to the family, a palace revolt among the captains (and with approval of the Commission) can replace the boss. Knowing this keeps most bosses in line.

Each captain oversees a number of wiseguys, each with his own crew of associates. These made-men know which cargos to hijack, which customer wants a loan, or how much a gambler can wager on a game. If this detailed information had to be transmitted back to the boss or captain for approval, not only would the opportunity be gone, but law enforcement most likely would intercept it. Accordingly, each boss empowers his captains, who then empower his wiseguys and their crews of associates to make the majority of the operating decisions. Since each wiseguy and his crew retain most of the spoils, the self-interest of each high performance team aligns with that of its family.
Promotion to captain is another key decision made by the boss. The boss, in consultation with his consigliere and under boss, decides who is good at what. Which criminal vice has a wiseguy acquired the specialized skill operating: gambling, hijacking, extortion, drugs, prostitution, or loansharking? Who has those qualities needed to be a shooter, wheelman, or lookout? Getting the right people in those positions where they have the unique talent increases the family's profits, and survival. Captains ascend to be boss with track records of assembling loyal crews that generate profits for the family. The boss has spent his life in the family. Having observed his made-men and captains for decades, the boss knows the accomplishments and shortcomings of his underlings - invaluable knowledge to use in promoting new captains and reassigning different rackets among existing captains.

Finally, depending on the vice, the captain will assign various tasks to made-men. For example, the captain of a loansharking operation may allow his made-men to lend any customer up to $\$ 1,000$, but amounts over this needs his approval. Or, an associate or wiseguy in charge of a prostitution bordello can deny entry to any john suspected of being an undercover police officer. While planning a robbery, the captain may assign the wheel man a detailed getaway route. But the wheel man can change the route during the getaway if he learns of road blocks from police scanners. In these examples, tasks are assigned to made-men or associates when they have better information than their captains, and they have incentives to make the decision that benefits the family.

Unlike lawful businesses, the Mafia did not need 17 meetings of numerous committees to decide which scam to run. Their highly decentralized task assignment pillar empowered small teams to move quickly and seize opportunities before they vanished. When assigning tasks, the Mafia follows the economic principle of tasking those groups or individuals such as the Commission, bosses, captains, and wiseguys if (1) they possess the relevant information and (2) face incentives to execute the task to benefit the family. 


\section{Performance Measurement Pillar}

Money and loyalty are the two primary currencies of the Mafioso's realm. Dollars generated for the family measure an earners' performance. A successful and efficient application of violence with minimal police interference and public notoriety measure a shooter's performance. Being a "standup guy" who goes above-and-beyond for the family when called upon demonstrates the made man's loyalty. Such fidelity can be just as important as ones' earnings or shootings as a motivator. These performance measures (money, devotion, and successful "hits") are unambiguous and easily understood.

Lawful firms also rely on loyalty as a performance measure. Having the reputation of being cooperative, a team player, and willing to go above-and-beyond usually enhances one's promotion chances, or landing a plum position elsewhere in the firm. While difficult to quantify, these subjective characteristics nonetheless provide important performance measures, and in some organizations, such as combat fighting units, often constitute the most important measures of performance.

\section{Performance Rewards/Punishments Pillar}

Some family bosses use a fixed rule as to how much money each crew keeps of their take, such as 85 percent. Other bosses vary the rate across crews because he wants to reward or penalize certain crews. For example, sloppy crews who generate more arrests and who require more family intervention and legal fees might retain less of their take. Whatever the actual rate, the performance reward is directly tied to the performance measure. Each crew's performance is measured as the cash generated, and their reward consists of a substantial fraction of that cash. Shooters receive cash for successful hits using standardized rates for killings versus just beatings.

Violence and its threat also provides an important part of the reward/punishment piece of the internal control system. Members and associates found stealing or committing other infractions results in beatings. Talking to law enforcement, breaking the code of silence, means death. One undercover FBI agent described wiseguys as, "the toughest among them feared their superiors. ${ }^{51}$

Becoming a wiseguy and once a wiseguy, being promoted to running a bigger crew, to captain, and maybe even to boss provides another important performance reward. One Mafia gangster dreamt of getting made, and becoming a true member of the Colombo family. "Getting made is the greatest thing that could ever happen to me," he said. "I been looking forward to this day ever since I was a kid." 52

Families promote associates to wiseguys after they prove themselves as earners in a particular vice or as shooters. Mobsters good at running gambling operations specialize in this vice, while those with skills at prostitution focus on those activities. Gaining and keeping respect of one's elders in the family and eventually being promoted are perhaps as

\footnotetext{
${ }^{51}$ Pistone (1987) p. 115.

52 Ibid., pp. 76-77.
}

powerful a motivator of Mafioso as money. Since ostentatious consumption attracts attention from the media and law enforcement, many mobsters chose to live a quiet, secluded life. They have little use for vast sums of money. To many it comes down to power and respect.

\section{Corporate Culture Pillar}

The American Mafia's corporate culture evolved from the earlier values and norms of the Sicilian Mafia. Italian and Sicilian immigrants to America brought an ethos of contempt for governmental authorities and reliance on their extended family and close friends for justice.

Crime boss, Joe Bonanno describes the culture of his family as, "Friendships, connections, family ties, trust, loyalty, obedience - this was the 'glue' that held us together." ${ }^{33}$ Three core values of the American Mafia's culture include: steadfast loyalty to the family, resourcefulness, and immorality. Being loyal earned one the moniker of being "a stand-up guy"-someone who refuses to rat out the Family no matter the pressure or threat. The underboss of the Colombo Family, John "Sonny" Franzese embodied loyalty. When facing prison time at age 93 he said, "They wanted me to roll all the time. I couldn't do that. Because it's my principle. I could never give a guy up because I knew what jail was. I wouldn't put a dog in a jail pod." 54

Made-men displayed resourcefulness, an entrepreneurial drive to find new criminal activities to exploit. Most wiseguys, in fact most criminals, are immoral. Immoral people know the difference between right and wrong, but do not care. They exhibit the following sociopathic behaviors: disrespect for social norms or laws, lying, deceiving others, and feeling no guilt or remorse for harming others. ${ }^{55}$ According to the undercover FBI agent who spent six years in the Mafia, most wiseguys regarded themselves as legitimate. They do not view themselves as being criminals or gangsters, but rather they view crime as acceptable, normal, and even honorable. ${ }^{56}$ One former Mafia underboss described killing as, "I had no feeling one way or another. I didn't enjoy it. I didn't dislike it. I did my job, my duty. All the guys I killed were like myself. Everybody was a bad guy. This was our life in La Cosa Nostra." ${ }^{57}$

Besides holding these three cultural values, the Mafia developed cultural norms - observed rituals - to reflect these values. The code of silence, omertà, forbids giving any information to public authorities. Omertà protects the family and reminds the mobster of the cultural value of loyalty. The code of silence and unwavering loyalty to the family were instilled in the formal initiation ceremony where the boss cuts the initiate's trigger finger who promises never to betray the family.

\footnotetext{
${ }^{53}$ Bonanno (1985) p. 406.

${ }^{54}$ Brown (2019)

$55 / /$ www.healthline.com/health/mental-health/sociopath\#diagnosis-andsymptoms

${ }^{56}$ Pistone (1987) p. 405

${ }^{57}$ Leonetti (2013).
} 


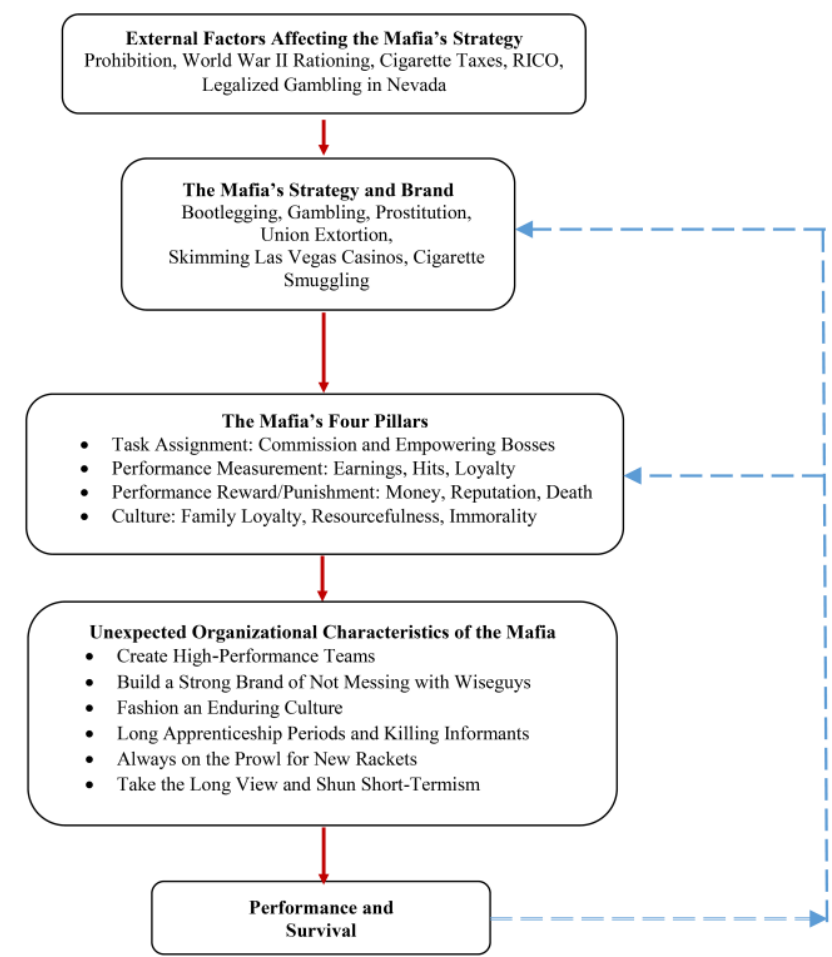

Fig. (2). Aligning Strategy and Structure.

How Government Regulation and Taxation Affect the Mafia's Strategy and the Four Pillars Required to Yield the Unexpected Organizational Characteristics.

Another cultural norm involved hanging out at a mobcontrolled bar or social club. The following describes the daily routine of a Mafioso.

When they got up in the morning, they didn't think about going to work and punching a time clock. They didn't think about spending time with their wives or girlfriends. The mob was their job. You got up, went to the club or wherever you hung out, and spent your day with those guys. You've got to be up all day figuring out what you're going to do that night, what scores you're going to go out on. The day basically was: You got to the club at ten-thirty or eleven o'clock in the morning, then sat around all day and discussed scams and scores and hustles, past and future. Somebody would have an idea about a burglary or hijack, and they'd kick it around to see if it was worthwhile. Or somebody else had pulled a score and was looking to get rid of jewelry, furs, or whatever. And they'd discuss the possibility of "middling" ittaking the swag and reselling it. ${ }^{58}$

The cultural norm of spending the day with one's crew reinforced loyalty to the family. It allowed the wiseguys and associates to keep track of each other, which reduces the risk of someone snitching. Face-to-face communications reduce the likelihood of a wiretap. It promoted initiative and innovation via teamwork within the crew. Target Corporation fosters teamwork among employees by encouraging them to stay connected through Facebook and other social media.
The Mafia fostered teamwork using social clubs and bars as hangouts to keep their crews connected.

Finally, unique nicknames like Scarface rather than real names was another important Mafia norm. It reflected the value of loyalty and reinforced the code of silence. Nicknames help protect the family from law enforcement by shielding the mobster's true identity. Also, unique nicknames, eliminated any confusion about the real person during conversations.

The Mafia's culture began shifting in the 1970s as mobsters born in Italy and Sicily died off or were imprisoned. They brought the values of the old country with them. They put the Family and their crew first. They honored and respected their bosses. Mafioso born in America did not possess as strong attachment to kinship and "family" as their predecessors. They wanted an easy life and many turned to drugs. ${ }^{59}$ This Americanization of the Mafia-coupled with law enforcement's concerted onslaught of investigations and indictments-eroded the mob's power.

\section{KEY FORENSIC FINDINGS}

Fig. (2) summarizes how the Mafia followed basic economic principles in aligning its strategy and Four Pillars. Starting with the top box in Fig. (2), numerous external events such as Prohibition, rationing during World War II, ever increasing cigarette taxes in New York, and the introduction of the RICCO statutes constantly forced the five families to revise their business strategies (see the box labeled "The Mafia's Strategy and Brand"). The Mafia exemplified the basic assumption of economics: people are self-interested, evaluative, and resourceful. When Nevada legalized gambling, the families changed strategies and opened lavish casinos. To accomplish this new strategy, the Commission had to revise its task assignment pillar to allow each family to operate in Las Vegas (see the box labeled "The Mafia's Four Pillars"). Besides opening Las Vegas casinos, the Mafia adopted the strategy of skimming their casino winnings before paying Nevada state taxes on these monies. The Mafia followed the economic principle of aligning the Four Principles to the current strategy.

The next box in Fig. (2) ("Unexpected Organizational Characteristics") describes the various characteristics of the Mafia's organization revealed by our forensic analysis. For example, their Four Pillars create high-performance teams that have built enduring cultures and a strong brand that shuns short-termism. It is these characteristics that have allowed the Mafia to profit and survive (see the last box). Finally, the dotted lines in Fig. (2) illustrate the feedback loop that caused the Mafia to continually evolve its strategy and Four Pillars based on past performance and changing market opportunities. For example, following the six-year FBI undercover operation in the 1970 s, the mob changed its rules for becoming a wiseguy. All proposed candidates had to kill someone because no undercover agent would commit murder.

\footnotetext{
${ }^{59}$ Pistone (1987) p. 405. 
As economic principles dictate, the Mafia engineered all four pillars to complement and reinforce each other. ${ }^{60}$ Each wiseguy is assigned day-to-day tasks where he has a record of accomplishment. He has current knowledge needed to operate this vice profitably. Then, that wiseguy's performance is judged based on the profits his vice generates, and his loyalty to the family. Finally, the wiseguy keeps a very high percentage of those profits, thereby insuring that he exercises his assigned tasks in ways that benefit both him and the family.

Performance measures and rewards, especially the fear of violence, create strong incentives for mobsters to behave in accordance with his captain's and boss' wishes. Another way the families controlled wiseguys involved the made-man's sponsor. All made-men must be sponsored by a captain, who then becomes responsible for the new member as long as the captain remains active in the family. So captains, not wanting to tarnish their reputations or incur other sanctions for sponsoring snitches, keep a close eye on who they back. Moreover, captains avoid sponsoring doubtful or dubious candidates. Hence, tying admission to a captain is a clever mechanism to insure that only the most extremely vetted candidates become made-men, and remain closely monitored by their sponsors. After the FBI infiltrated the Mafia, the mob required all proposed candidates to commit a murder and two Mafiosi now must vouch for, and assume responsibility of a proposed member. ${ }^{61}$

Finally, the three key cultural values of the Mafia's culture $\square$ steadfast loyalty, resourcefulness, and immoralityreinforce the first three pillars in several ways. First, everyone knows that breaking the code of silence almost certainly results in death-the third pillar: punishing unwanted performance. The formal initiation ritual made this perfectly clear. Second, being immoral allows wiseguys to dispense violence to maintain the mob's monopoly in its vice, thereby generating profits, and to discipline mob members who violate the rules. Third, wannabees spend years of cultural indoctrination before becoming made men. Just like the United States military academies seek to instill in their cadets the qualities of moral excellence to do the right thing, the Mafia also trains its initiates to do immoral things. Fourth, the Mafia prunes people who do not share these cultural values. Military academies seek to build character and leadership skills through their four-year academy programs. Unfortunately, the "right things" constitute very different behaviors in these two very diverse institutions. The Mafia's training programs often extend ten years or more, before the associate attains membership as a made man. Despite their very different moral values, military academies and the Mafia rely on their cultures-values and norms-to educate their new initiates about the behaviors expected of them. Cadets and Mafia wannabees not possessing the desirable cultural attributes wash out.

\footnotetext{
${ }^{60}$ For a discussion of complementarities, see Milgrom and Roberts (1995) pp. 179-208.

${ }^{61}$ Pistone (1987) p. 405.
}

Finally, the Mafia rewards loyalty—being a stand-up guy of going above-and-beyond for the family. If incarcerated, stand-up guys expect the boss will support his family. Standup guys often get promoted to captain and assigned more covetable jobs or more lucrative robberies.

\section{CONCLUSION}

This paper examines how the American Mafia applied fundamental economic principles to align its constantly changing strategy with its task assignments, performance measures and rewards, and culture - the Four Pillars. The American Mafia evolved very sophisticated Four Pillars, ones as refined as many successful corporations, be it Starbucks, Southwest Airlines, or Amazon. Each of the Four Pillars reflects the unique criminal underground environment within which the mob operates. Rewarding loyalty and holding captains responsible for those they sponsor foster incentives that shun short-termism. Such organizational innovations as the Commission illustrate how despicable people redesign their Four Pillars to survive by reining in extreme greed while channeling self-interest to produce wealth.

Important differences exist between lawful and unlawful organizations' Four Pillars, particularly with respect to the deployment of extreme physical violence. Lawful firms seek out moral employees, whereas the Mafia's cultural value of immorality attracts people capable of hurting others. Additionally, crime syndicates are deprived the use of courts to enforce contracts and financial institutions to facilitate trade, so they must devise alternatives. These differences prevent lawful leaders from simply copying the Mafia's Four Pillars. Although lawful firms and unlawful firms differ in significant ways, each develops specific Four Pillars adapted to its unique situation. Nonetheless, lawful managers must design their own Four Pillars using the same well-accepted economic principles as the Mafia.

\section{CONFLICT OF INTEREST STATEMENT}

The authors declare that they have no conflict of interest.

\section{REFERENCES}

Abadinsky. H. Organized Crime (Cengage Learning. Kindle Edition, 2017). Anderson, A. "Organized Crime, Mafia and Governments," The Economics of Organized Crime, Edited by Gianluca Fiorentini and Sam Peltzman (Cambridge U.K.: Cambridge University Press, 1995) pp. 33-54.

Bonanno, J. (with S. Lalli). A Man of Honor: The Autobiography of Joseph Bonanno (New York: Simon and Schuster, 1985) P. 10-11.

Brickley J., C. Smith, and J. Zimmerman, Managerial Economics and Organizational Architecture, (New York: McGraw-Hill Education, 2016).

Brown, L. "102-year-old Mobster: 'I Never Hurt Nobody that Was Innocent' NY Post (March 27, 2019) //nypost.com/2019/03/27/102year-old-mobster-i-never-hurt-nobody-that-was- innocent/

Chandler, A.D., Jr. Strategy and Structure: Chapters in the History of the Industrial Enterprise (M.I.T. Press, 1962).

Cressey, D. Theft of the Nation: The Structure and Operations of Organized Crime in America (Harper Colophon Books, 1969).

Davis, J. Mafia Dynasty: The Rise of the Gambino Crime Family (New York: Harper Torch, 1993).

Gardiner, S. and P. Shallwani. "Mafia is Down but not Out," Wall Street Journal (Feb 18, 2014). Hobsbawm, E. On History (New Press, 1997). 
Lacey, R. Little Man: Meyer Lansky and the Gangster Life (Little, Brown and Company, 1991). Leonetti, P. "Inside the American Mob," National Geographic TV Series (Episode 3), 2013.

Mbetta, D. and P. Reuter, "Conspiracy Among the Many: The Mafia in Legitimate Industries" The Economics of Organized Crime, Edited by G. Fiorentini and S. Peltzman (Cambridge University Press, 1995).

Milgrom, P. and J. Roberts. "Complementarities and Fit Strategy, Structure, and Organizational Change in Manufacturing," Journal of Accounting and Economics 19 (May 1995).

Nelli, H., The Business of Crime: Italians and Syndicate Crime in the United States (Chicago: University of Chicago Press, 1976)

Pistone, J. Donnie Brasco (Penguin Publishing Group. Kindle Edition, 1987).

Raab, S. Five Families: The Rise, Decline, and Resurgence of America's Most Powerful Mafia Empires (St. Martin's Press, Kindle Edition 2005).
Reuter, P. "The Decline of the American Mafia," Public Interest (Summer 1995).

Walsh, S. "120 Charged in Probe Of Mob on Wall St." Washington Post (June 15, 2000)

www.washingtonpost.com/archive/politics/2000/06/15/120-

charged-in-probe-of-mob-on- wall-st/50ee710e-6e13-4c3e-8b0e$7 \mathrm{a} 47 \mathrm{f} 317 \mathrm{bf} 12 /$ ?noredirect=on\&utm term $=.157 \mathrm{f5} \mathrm{cf} 85 \mathrm{ffe}$

Wharton Econometrics Forecasting Associates. "The Income of Organized Crime." in Report to the President and the Attorney General: The Impact: Organized Crime Today (U.S. Government Printing Office 1986).

Zingales. L. "The 'Cultural Revolution' in Finance, "Journal of Financial Economics 117 (2015) pp. 1-4.

Received: Nov 02, 2020

Copyright ( 2020- All Rights Reserved

This is an open-access article. 